\title{
Potassium/Energy and Phosphorus/Calcium Ratios Reflect the Quality of Nutrition
}

\author{
Katsushi YOSHITA*1, Hideaki NAKAGAWA*1, Masaji TABATA*1, \\ Yuko MORIKAWA*1, Muneko NISHIJO*1, Masami SENMA*1, \\ Katsuyuki MIURA*1, Masao ISHIZAKI*2, Teruhiko KIDO*3 \\ and Shunichi KAWANO*1 \\ ${ }^{* 1}$ Department of Public Health, Kanazawa Medical University, Ishikawa \\ *2 Department of Hygiene, Kanazawa Medical University, Ishikawa \\ ${ }^{* 3}$ Department of Hygiene, School of Medicine, Chiba University, Chiba
}

\begin{abstract}
A nutritional survey and questionnaire regarding dietary habits were administered to 649 men ranging in age from 35 to 64 years receiving a one-day health screening examination. First, comparisons of nutrient intake based on the nutrient rate of the Recommended Dietary Allowances for Japanese (RDA), and the total score on the questionnaire regarding dietary habits according to the RDA rates of total energy and calcium (Ca) were investigated. Then, the comparisons of intake of food groups, intake of nutrients and the total score on the questionnaire regarding dietary habits according to potassium/energy (K/E) ratio and phosphorus/calcium $(\mathrm{P} / \mathrm{Ca})$ ratio were determined. Last, differences between comparisons with the nutrient rates of $\mathrm{RDA}$ and comparisons with $\mathrm{K} / \mathrm{E}$ ratio and $\mathrm{P} / \mathrm{Ca}$ ratio were investigated.

The following results were obtained:

1. Even in the group with RDA rates of total energy or Ca of $\geqq 90 \%$ and $\leqq 110 \%$ the RDA rates of some other nutrients were out-side the appropriate range.

2 . In the group with high $\mathrm{K} / \mathrm{E}$ ratios, as compared to the group with low ratios, the intake of potatoes, pulses, fruits, green/yellow vegetables, other vegetables, soy sauce, other beverages, fish/shellfish, and milk products showed high values, while cereals and fats/ oils showed low values. For this reason, in the former group as compared to the latter, the intake and RDA total energy rate showed low values whereas the intake and RDA rates of nutrients such as $\mathrm{Ca}, \mathrm{Fe}$, and vitamin $\mathrm{A}$ were low.

3 . In the group with high $\mathrm{P} / \mathrm{Ca}$ ratios, as compared to the group with low ratios, the intake of beer and meats showed high values while that of pulses, green/yellow vegetables, and milk products showed low values. For this reason, in the former group as compared to the other groups, despite the fact that the intake and RDA total energy rate tended to be higher, the intake of nutrients such as $\mathrm{Ca}, \mathrm{P}, \mathrm{K}$, and vitamin A showed lower values.

4. The RDA rates of all of the nutrients of group with a high $\mathrm{K} / \mathrm{E}$ ratio and the group with a low $\mathrm{P} / \mathrm{Ca}$ ratio generally showed largely appropriate values.

5 . These results suggest that indices reflecting the balance of minerals such as the $\mathrm{K} / \mathrm{E}$ and $\mathrm{P} / \mathrm{Ca}$ ratios more objectively reflect the quality of nutrition than comparisons based on the RDA rates of total energy and specific-nutrient.
\end{abstract}

Key words : Potassium/energy ratio, Phosphorus/calcium ratio, Intake of nutrients, Intake of food groups, Nutrient rate of Recommended Dietary Allowances, Dietary habits

Reprint requests to : Katsushi Yoshita, Department of Public Health, Kanazawa Medical University, 1-1, Daigaku, Uchinada, Ishikawa, 920-02, Japan 


\section{Introduction}

The steady intake of appropriate quantities of nutrients is indispensable for the maintenance and improvement of health as well as the prevention and treatment of various diseases. Paralleling the economic development of Japan in recent years, a diversity of food stuffs has become widely available, leading to what at first glance appears to be a marked improvement in the national diet. However, with the keeping of later hours and an increase in the number of persons living apart from their families, various diet-related problems, including late night eating, skipping of breakfast, and an increasing reliance on processed foods are becoming ever more serious ${ }^{1 \sim 3)}$. Such dietary habits have contributed to a markedly disturbed balance of ingested nutrients, and it is speculated that even when the total energy intake itself is appropriate these habits may have a major impact on the balance of nutrients, particularly that of minerals, contained in the $\operatorname{diet}^{4 \sim 6)}$.

In this regard, increasing attention has been focused on the relation between the unbalanced intake of minerals and the development of conditions such as taste disorders, osteoporosis, renal and ureteral stones, and ischemic heart disease $^{7 \sim 10)}$.

In the present study, on the basis of food diaries provided by persons attending a one-day health screening examination, the total energy (E) and calcium (Ca) intake rates of Recommended Dietary Allowances for Japanese (RDA) were determined. Then, the relationships between these two RDA rates and the intake and RDA rates of other nutrients as well as various dietary habits such as skipping meals, determined from a questionnaire administered at the same time, were investigated. However, it was considered difficult to evaluate the status of nutrient intake from the intake of total energy or single nutrients, so we focused on the ratios of potassium/ total energy $(\mathrm{K} / \mathrm{E})$ and phosphorus/calcium $(\mathrm{P} /$
Ca) intake. We investigated the relations between these ratios and the intakes of individual food groups and those of nutrients and RDA nutrient rates.

\section{Materials and methods}

Six hundred and forty - nine male civil servants ranging in age from 35 to 64 years who received a one-day health screening examination during the one-year period from April 1990 through March 1991 were studied. Table 1 shows the age distribution of these subjects. Prior to the health examination the subjects were given questionnaire forms on which they were asked to record the content of their diet during a 3-day period and, to answer a series of questions concerning their dietary habits, in particular those related to overeating, as listed in Table 2 , and which they were asked to bring with them on the day of the health examination. A dietician then conducted direct interviews with each subject to confirm and revise the recorded diet content. After averaging the 3-day diet content, the total energy intake and amount of ingested nutri-

\section{Table 1 Subjects investigated by age}

\begin{tabular}{cc}
\hline Age & Number of subjects $(\%)$ \\
\hline $30 \sim 39$ & $92(14.2)$ \\
$40 \sim 49$ & $401(61.8)$ \\
$50 \sim 59$ & $151(23.3)$ \\
$60 \sim 69$ & $5(0.8)$ \\
\hline Total & $649(100.0)$ \\
\hline
\end{tabular}

Table 2 Questions regarding dietary habits

\begin{tabular}{|c|c|c|}
\hline 1. Are you uninterested in eating? & Yes & No \\
\hline 2. Do you tend to eat until becoming full? & Yes & No \\
\hline 3. Do you tend to eat quickly? & Yes & No \\
\hline 4. Do you sometimes omit breakfast? & Yes & No \\
\hline 5. Do you sometimes omit lunch? & Yes & No \\
\hline 6. Do you sometimes eat lunch after 2 PM? & Yes & No \\
\hline 7. Do you sometimes eat between meals? & Yes & No \\
\hline 8. Do you sometimes eat dinner after 8 PM? & Yes & No \\
\hline $\begin{array}{l}\text { 9. Do you consume }<50 \% \text { of your daily } \\
\text { intake at dinner time? }\end{array}$ & Yes & No \\
\hline 10. Do you sometimes snack at night? & Yes & No \\
\hline
\end{tabular}


ents were calculated referring to the 4 th Revised Standard Tables of Food Composition in Japan 11). In addition, the intake according to individual food groups was calculated based on the classification of the National Nutrition Survey ${ }^{12)}$. Also, when possible, the RDA nutrient rate was calculated by dividing the total energy intake and amount of each nutrient ingested by each subject by the corresponding $\mathrm{RDA}^{13}$. At this time, in the case of allowances with a range of values, an intermediate value was adopted. On the questionnaire relating to dietary habits, answers indicating inappropriate and appropriate dietary habits were assigned scores of zero and one point, respectively, and the total score was calculated. With regard to questions 4 to 10 , a frequency of three times per week or more was regarded as a positive answer .

\section{Results}

\section{Division of groups according to the $K / E$ ratio and $\mathrm{P} / \mathrm{Ca}$ ratio}

The $\mathrm{K} / \mathrm{E}$ ratio was determined in each subject, and the subjects were divided into $<25$ th percentile, 25 - 75 th percentile, and $\geqq 75$ th percentile groups. The group with low values of $<102.30$ $\times 10^{-2}(\mathrm{mg} / \mathrm{kcal})$ was designated as Group A, that with high values of $\geqq 135.6 \times 10^{-2}(\mathrm{mg} / \mathrm{kcal})$ as Group C, and that with intermediate values as Group B.

Table 3 Comparison of body parameters according to the potassium/total energy $(K / E)$ ratio

\begin{tabular}{lrrc}
\hline & $\begin{array}{c}\text { Group A } \\
(\mathrm{n}=162)\end{array}$ & $\begin{array}{c}\text { Group B } \\
(\mathrm{n}=325)\end{array}$ & $\begin{array}{c}\text { Group C } \\
(\mathrm{n}=162)\end{array}$ \\
\hline Age & $44.5 \pm 6.2$ & $45.3 \pm 5.7$ & $46.7 \pm 5.9 \& \&$ \\
Height $(\mathrm{cm})$ & $169.3 \pm 5.2$ & $169.1 \pm 5.3$ & $168.4 \pm 5.1$ \\
Weight $(\mathrm{kg})$ & $70.8 \pm 9.7$ & $69.5 \pm 9.1$ & $69.0 \pm 8.2$ \\
BMI $\left(\mathrm{kg} / \mathrm{m}^{2}\right)$ & $24.6 \pm 2.8$ & $24.3 \pm 2.8$ & $24.3 \pm 2.7$ \\
\hline
\end{tabular}

Mean \pm S.D.

$\& \&: p<0.01$, significant difference from Group A

Group A : the group with low $\mathrm{K} / \mathrm{E}$ values of less than $102.30 \times 10^{-2}(\mathrm{mg} / \mathrm{kcal})$

Group B : the group with intermediate $\mathrm{K} / \mathrm{E}$ values

Group C : the group with high $\mathrm{K} / \mathrm{E}$ values of more than $135.65 \times 10^{-2}(\mathrm{mg} / \mathrm{kcal})$
Similarly, the subjects were divided into three groups according to the $\mathrm{P} / \mathrm{Ca}$ ratio $(<25$ th percentile, 25 - 75 th percentile, and $\geqq 75$ th percentile groups). The group with low values of $<1.866$ was designated as Group I, that with high values of $\geqq 2.601$ as Group III, and that with intermediate values as Group II.

Tables 3 and 4 show comparisons of physical parameters according to the $\mathrm{K} / \mathrm{E}$ ratio and $\mathrm{P} /$ Ca ratio respectively. No differences in height, weight or body mass index (BMI) were noted between the groups divided according to either ratio, although a difference was seen in age. For this reason, comparisons of food intake groups and nutrient intake accoriding to the $\mathrm{K} / \mathrm{E}$ ratio and $\mathrm{P} / \mathrm{Ca}$ ratio were made using two-way $\mathrm{ANO}-$ $\mathrm{VA}$ with the $\mathrm{K} / \mathrm{E}$ ratio or $\mathrm{P} / \mathrm{Ca}$ ratio and age as factors to adjust the age. Then, for items showing significant differences among the three $\mathrm{K} / \mathrm{E}$ ratio or $\mathrm{P} / \mathrm{Ca}$-ratio groups, differences between two of these groups were tested by using Scheffe's test ${ }^{14)}$.

2. Comparison of intake of nutrients, RDA nutrient rate and total score on the dietary habits questionnaire according to the RDA total energy rate and RDA Ca rate

The subjects were divided into three groups according to their total RDA energy rate $(<90 \%$, $\geqq 90$ - $\leqq 110 \%,>110 \%)$. They were similarly divided according to their RDA Ca rate.

Table 4 Comparison of body parameters according to the phosphorus/calcium $(\mathrm{P} / \mathrm{Ca})$ ratio

\begin{tabular}{lccc}
\hline & $\begin{array}{c}\text { Group I } \\
(\mathrm{n}=163)\end{array}$ & $\begin{array}{c}\text { Group II } \\
(\mathrm{n}=324)\end{array}$ & $\begin{array}{c}\text { Group III } \\
(\mathrm{n}=162)\end{array}$ \\
\hline Age & $46.8 \pm 6.2$ & $45.4 \pm 5.9^{\$}$ & $44.3 \pm 5.6^{\& \&}$ \\
Height $(\mathrm{cm})$ & $168.9 \pm 5.5$ & $168.9 \pm 5.4$ & $169.3 \pm 4.6$ \\
Weight $(\mathrm{kg})$ & $69.2 \pm 9.2$ & $69.3 \pm 9.1$ & $70.9 \pm 8.7$ \\
BMI $\left(\mathrm{kg} / \mathrm{m}^{2}\right)$ & $24.3 \pm 2.9$ & $24.2 \pm 2.7$ & $24.7 \pm 2.8$ \\
\hline
\end{tabular}

Mean \pm S.D.

$\$: p<0.05$, significant difference from Group I $\& \&: p<0.01$, significant difference from Group I Group I : the group with low $\mathrm{P} / \mathrm{Ca}$ values of less than 1.866

Group II : the group with intermediate $\mathrm{P} / \mathrm{Ca}$ values Group III : the group with high $\mathrm{P} / \mathrm{Ca}$ values of more than 2.601 
Tables 5 and 6 show comparisons of physical parameters, intake of nutrients and RDA nutrient rates, and results of the questionnaire on dietary habits according to the RDA rates of total energy and $\mathrm{Ca}$, respectively. These RDA rates were based on nutritional requirements determined taking into account the intensity of physical activity, age, and height. Here, one-way ANOVA was performed, and for items showing significant differences between the three goups comparisons between two of these groups were performed using Scheffe's test ${ }^{15)}$.

The intakes of total energy, protein, lipid, carbohydrate, $\mathrm{Ca}, \mathrm{P}, \mathrm{K}$, sodium $(\mathrm{Na})$, vitamin $\mathrm{B} 1$, and vitamin $\mathrm{B} 2$, and the RDA rates of pro- tein, lipid, Ca, vitamin B1, and vitamin B2 all showed increasingly high values in the groups with higher RDA total energy rates (Table 5). The intake of iron in the group with a RDA total energy rate of $>110 \%$ was higher than that of the other 2 groups. The intake of vitamin $A$ in the group with a RDA total energy rate of $>110 \%$ was higher than that of the group with a RDA total energy rate of $<90 \%$. In the total score on the dietary habits questionnaire the $\geqq 90-\leqq 110 \%$ group showed higher values than the $>110 \%$ group.

The intakes of energy, protein, lipid, $\mathrm{Ca}$, $\mathrm{P}, \mathrm{K}$, vitamin $\mathrm{A}$, vitamin $\mathrm{B} 2$, and vitamin $\mathrm{C}$, and the RDA rates of total energy, protein, lipid, iron, vitamin $A$, vitamin $B 2$ and vitamin

Table 5 Comparisons of intake of nutrients, RDA nutrient rate and dietary habits according to the RDA total energy rate

\begin{tabular}{|c|c|c|c|c|}
\hline \multicolumn{2}{|l|}{ RDA total energy rate } & $\begin{array}{c}<90 \% \\
(n=258)\end{array}$ & $\begin{array}{c}\geqq 90 \%, \leqq 110 \% \\
(\mathrm{n}=270)\end{array}$ & $\begin{array}{l}>110 \% \\
(n=121)\end{array}$ \\
\hline \multicolumn{5}{|l|}{ Characteristics of participants } \\
\hline Age & (Years) & $45.3 \pm 6.2$ & $45.5 \pm 5.7$ & $45.7 \pm 6.0$ \\
\hline Height & $(\mathrm{cm})$ & $169.5 \pm 5.1$ & $169.0 \pm 5.5$ & $167.9 \pm 4.8^{b}$ \\
\hline Weight & $(\mathrm{kg})$ & $68.9 \pm 8.6$ & $69.7 \pm 9.1$ & $71.1 \pm 9.7$ \\
\hline $\mathrm{BMI}$ & $\left(\mathrm{kg} / \mathrm{m}^{2}\right)$ & $24.0 \pm 2.6$ & $24.4 \pm 2.8$ & $25.2 \pm 2.9 \mathrm{bbc}$ \\
\hline \multicolumn{5}{|l|}{ Intake of nutrients } \\
\hline Total energy & (kcal) & $1710.4 \pm 247.0$ & $2083.6 \pm 197.2^{\text {aa }}$ & $2530.5 \pm 319.9 \mathrm{bbcc}$ \\
\hline Protein & (g) & $67.1 \pm 13.0$ & $80.3 \pm 15.8^{\mathrm{aa}}$ & $96.1 \pm 23.7 \mathrm{bbcc}$ \\
\hline Lipid & $(\mathrm{g})$ & $41.2 \pm 11.8$ & $52.0 \pm 14.5^{\text {aa }}$ & $64.3 \pm 21.5^{\mathrm{bbcc}}$ \\
\hline Carbohydrates, non-fibrous & $(\mathrm{g})$ & $230.5 \pm 43.4$ & $271.7 \pm 45.4^{\text {aa }}$ & $323.1 \pm 60.7^{\text {bbcc }}$ \\
\hline Calcium & $(\mathrm{mg})$ & $446.7 \pm 168.6$ & $498.7 \pm 181.8^{\text {aа }}$ & $571.2 \pm 224.6^{\text {bbcc }}$ \\
\hline Phosphorus & (mg) & $918.7 \pm 193.7$ & $1074.2 \pm 224.3^{\text {aa }}$ & $1267.6 \pm 292.5 \mathrm{bbcc}$ \\
\hline Iron & $(\mathrm{mg})$ & $8.0 \pm 2.0$ & $9.2 \pm 2.7$ & $11.4 \pm 12.5 \mathrm{bbcc}$ \\
\hline Potassium & $(\mathrm{mg})$ & $2210.0 \pm 553.4$ & $2497.0 \pm 703.2^{\mathrm{aa}}$ & $2713.9 \pm 706.2^{\mathrm{bbcc}}$ \\
\hline Sodium & (mg) & $3872.9 \pm 1291.9$ & $4333.6 \pm 1286.5^{\text {aa }}$ & $4807.3 \pm 1742.3^{b b c c}$ \\
\hline Vitamin A & (IU) & $1626.2 \pm 1112.4$ & $1862.9 \pm 1304.3$ & $1993.5 \pm 1266.6^{\mathrm{b}}$ \\
\hline Vitamin B1 & (mg) & $0.74 \pm 0.27$ & $0.89 \pm 0.30^{\mathrm{a}}$ & $1.11 \pm 0.64^{\mathrm{bbcc}}$ \\
\hline Vitamin B2 & (mg) & $1.03 \pm 0.35$ & $1.18 \pm 0.38^{\text {aa }}$ & $1.46 \pm 0.58 \mathrm{bbcc}$ \\
\hline Vitamin C & (mg) & $68.6 \pm 39.1$ & $69.9 \pm 34.4$ & $72.2 \pm 38.3$ \\
\hline \multicolumn{5}{|l|}{ RDA nutrient rate } \\
\hline Protein & $(\%)$ & $93.1 \pm 16.6$ & $113.6 \pm 21.3^{\text {aa }}$ & $139.3 \pm 32.6^{\text {bbcc }}$ \\
\hline Lipid & $(\%)$ & $75.9 \pm 18.9$ & $99.7 \pm 25.5^{\text {aa }}$ & $127.0 \pm 39.5 \mathrm{bbcc}$ \\
\hline Calcium & $(\%)$ & $71.3 \pm 25.4$ & $81.0 \pm 28.7$ aа & $96.1 \pm 38.6^{\mathrm{bbcc}}$ \\
\hline Iron & $(\%)$ & $80.9 \pm 19.6$ & $94.3 \pm 27.0^{\text {aa }}$ & $107.3 \pm 24.8^{\mathrm{bbcc}}$ \\
\hline Vitamin A & $(\%)$ & $85.0 \pm 59.4$ & $94.3 \pm 65.8$ & $101.6 \pm 63.3$ \\
\hline Vitamin $B 1$ & $(\%)$ & $94.9 \pm 31.5$ & $115.4 \pm 32.3^{\text {aa }}$ & $146.0 \pm 74.7 \mathrm{bbcc}$ \\
\hline Vitamin B2 & $(\%)$ & $92.4 \pm 26.0$ & $110.0 \pm 29.3^{\mathrm{aa}}$ & $138.5 \pm 51.2^{\text {bbcc }}$ \\
\hline Vitamin C & $(\%)$ & $135.4 \pm 73.4$ & $140.5 \pm 68.4$ & $152.8 \pm 84.4$ \\
\hline Total score for dietary habits & & $6.6 \pm 1.8$ & $6.8 \pm 1.9$ & $6.2 \pm 1.9^{\mathrm{c}}$ \\
\hline
\end{tabular}

mean \pm standard deviation

a : $p<0.05$, aa : $p<0.01$, significant difference from the $<90 \%$ group

$\mathrm{b}: \mathrm{p}<0.05, \mathrm{bb}: \mathrm{p}<0.01$, significant difference from the $<90 \%$ group

c : $p<0.05$, cc $: p<0.01$, significant difference from the $\geqq 90 \%$ and $\leqq 110 \%$ group

RDA : Recommended Dietary Allowances for Japanese 
Jpn. J. Hyg. , Vol. 48, No. 6, February 1994

Table 6 Comparisons of intake of nutrients, RDA nutrient rate and dietary habits according to RDA Calcium rate

\begin{tabular}{|c|c|c|c|c|}
\hline \multicolumn{2}{|l|}{ RDA calcium rate } & $\begin{array}{c}<90 \% \\
(\mathrm{n}=439)\end{array}$ & $\begin{array}{c}\geqq 90 \%, \leqq 110 \% \\
(\mathrm{n}=127)\end{array}$ & $\begin{array}{l}>110 \% \\
(n=83)\end{array}$ \\
\hline \multicolumn{5}{|l|}{ Characteristics of participants } \\
\hline Age & (Years) & $45.0 \pm 6.0$ & $46.1 \pm 5.8$ & $46.7 \pm 5.9$ \\
\hline Height & $(\mathrm{cm})$ & $169.2 \pm 5.2$ & $168.7 \pm 5.0$ & $168.5 \pm 5.8$ \\
\hline Weight & $(\mathrm{kg})$ & $69.5 \pm 8.9$ & $70.1 \pm 8.5$ & $69.6 \pm 10.4$ \\
\hline BMI & $\left(\mathrm{kg} / \mathrm{m}^{2}\right)$ & $24.3 \pm 2.7$ & $24.6 \pm 2.8$ & $24.5 \pm 3.3$ \\
\hline \multicolumn{5}{|l|}{ Intake of nutrients } \\
\hline Total energy & (kcal) & $1965.7 \pm 361.8$ & $2070.3 \pm 380.0^{\mathrm{a}}$ & $2218.7 \pm 428.9 \mathrm{bbc}$ \\
\hline Protein & $(\mathrm{g})$ & $73.6 \pm 15.3$ & $80.7 \pm 15.8^{\text {aa }}$ & $96.9 \pm 30.8 \mathrm{bbcc}$ \\
\hline Lipid & $(\mathrm{g})$ & $47.1 \pm 16.7$ & $53.2 \pm 17.0^{\text {aa }}$ & $60.4 \pm 16.3^{\mathrm{bbcc}}$ \\
\hline Carbohydrates, non-fibrous & $(\mathrm{g})$ & $261.9 \pm 58.1$ & $267.6 \pm 53.2$ & $276.8 \pm 65.9$ \\
\hline Calcium & $(\mathrm{mg})$ & $398.2 \pm 111.7$ & $606.5 \pm 88.4^{\text {aa }}$ & $809.3 \pm 199.5^{\text {bbcc }}$ \\
\hline Phosphorus & $(\mathrm{mg})$ & $959.0 \pm 188.5$ & $1139.1 \pm 184.8^{\text {aa }}$ & $1383.0 \pm 350.0^{\mathrm{bbcc}}$ \\
\hline Iron & (mg) & $8.2 \pm 1.9$ & $9.5 \pm 2.2$ & $13.2 \pm 15.0^{\mathrm{bbcc}}$ \\
\hline Potassium & (mg) & $2230.5 \pm 480.7$ & $2625.1 \pm 494.6^{\text {aа }}$ & $3134.8 \pm 1099.0^{b b c}$ \\
\hline Sodium & (mg) & $4182.6 \pm 1405.8$ & $4406.4 \pm 1452.2$ & $4279.6 \pm 1474.2$ \\
\hline Vitamin A & (IU) & $1618.0 \pm 1157.4$ & $1976.5 \pm 1148.6^{\mathrm{a}}$ & $2438.8 \pm 1464.8^{b b c}$ \\
\hline Vitamin B1 & (mg) & $0.83 \pm 0.34$ & $0.88 \pm 0.29$ & $1.06 \pm 0.69 \mathrm{bbcc}$ \\
\hline Vitamin B2 & (mg) & $1.04 \pm 0.33$ & $1.33 \pm 0.34^{\mathrm{aa}}$ & $1.65 \pm 0.65 \mathrm{bbcc}$ \\
\hline Vitamin C & (mg) & $63.2 \pm 32.4$ & $75.5 \pm 33.6^{\mathrm{aa}}$ & $96.0 \pm 50.1^{\mathrm{bbcc}}$ \\
\hline \multicolumn{5}{|l|}{ RDA nutrient rate } \\
\hline Total energy & $(\%)$ & $92.2 \pm 16.6$ & $98.9 \pm 18.3^{\text {aa }}$ & $106.5 \pm 21.4^{\mathrm{bbcc}}$ \\
\hline Protein & $(\%)$ & $103.4 \pm 20.8$ & $114.9 \pm 21.4^{\mathrm{aa}}$ & $139.4 \pm 44.2^{\mathrm{bbcc}}$ \\
\hline Lipid & $(\%)$ & $88.8 \pm 30.8$ & $103.9 \pm 31.1^{\text {aa }}$ & $116.6 \pm 30.1^{b b c}$ \\
\hline Iron & $(\%)$ & $84.0 \pm 19.1$ & $98.9 \pm 21.1^{\text {aa }}$ & $119.4 \pm 38.0^{\mathrm{bbcc}}$ \\
\hline Vitamin A & $(\%)$ & $83.6 \pm 60.7$ & $100.3 \pm 56.9^{\mathrm{a}}$ & $123.8 \pm 72.8^{b b c}$ \\
\hline Vitamin B1 & $(\%)$ & $107.2 \pm 38.0$ & $116.3 \pm 34.6$ & $138.6 \pm 83.2^{\mathrm{bbcc}}$ \\
\hline Vitamin B2 & $(\%)$ & $95.8 \pm 26.4$ & $122.5 \pm 25.5^{\mathrm{aa}}$ & $152.6 \pm 55.3^{\mathrm{bbcc}}$ \\
\hline Vitamin C & $(\%)$ & $126.8 \pm 62.8$ & $155.1 \pm 71.2^{\mathrm{aa}}$ & $192.5 \pm 100.3^{\mathrm{bbcc}}$ \\
\hline Total score for dietary habits & & $6.6 \pm 1.8$ & $6.7 \pm 1.9$ & $6.5 \pm 1.9$ \\
\hline
\end{tabular}

mean \pm standard deviation

a : $p<0.05$, aa : $p<0.01$, significant difference from the $<90 \%$ group

b : $p<0.05$, bb : $p<0.01$, significant difference from the $<90 \%$ group

c $: p<0.05$, cc $: p<0.01$, significant difference from the $\geqq 90 \%$ and $\leqq 110 \%$ group

RDA : Recommended Dietary Allowances for Japanese

$\mathrm{C}$ rates all showed increasingly high values in the groups with higher RDA Ca rates (Table 6). The intakes and RDA rates of iron and vitamin $B 1$ showed higher values in the group with a RDA Ca rate of $>110 \%$ as compared to the other 2 groups. However, the total score on the dietary habits questionnaire did not differ among the three groups.

\section{Comparison of intake of food by food groups according to the $\mathrm{K} / \mathrm{E}$ ratio and $\mathrm{P} / \mathrm{Ca}$ ratio}

As shown in Table 7, in the comparison of the $\mathrm{K} / \mathrm{E}$ ratio, in Group $\mathrm{C}$ with the other two groups, the intake of potatoes, pulses, fruits, green/yellow vegetables, other vegetables, soy sauce, other beverages, fish/shellfish, and milk products was high, while that of cereals and fats/ oils was low.

Although not shown in the Table, the energy intake according to food groups also showed high values in Group C for potatoes, pulses, fruits, green/yellow vegetables, soy sauce, and fish and shellfish, and low values for cereals and fats/ oils, with these results virtually the same as those of the study on intake according to food groups.

As shown in Table 8, in Group I, with a low $\mathrm{P} / \mathrm{Ca}$ ratio, as compared to the other two groups, the intake of cereals was low, while that of pulses and milk products was high. In contrast, in Group III with a high $\mathrm{P} / \mathrm{Ca}$ ratio, as com- 
Jpn. J. Hyg. , Vol. 48, No. 6, February 1994

Table 7 Comparison of intake of foods by food groups according to the $\mathbf{K} / \mathbf{E}$ ratio (g/day)

\begin{tabular}{|c|c|c|c|}
\hline & Group A & Group B & Group C \\
\hline Cereals & 657.5 & $587.1^{\$ \$}$ & 489.9 \&\&¥¥ \\
\hline Nuts and Seeds & 0.8 & 1.7 & 0.8 \\
\hline Potatoes & 25.6 & $36 \cdot 3^{\$}$ & $52.0^{8 \& \& ¥}$ \\
\hline Sugars & 8.6 & 7.4 & 6.6 \\
\hline Confectioneries & 10.0 & 7.1 & 5.9 \\
\hline Fats and Oils & 17.6 & $14.0^{\$ \$}$ & $10.2^{\& \& ¥ ¥}$ \\
\hline Pulses & 73.8 & 89.5 & 117.1 \&\&㛙 \\
\hline Fruits & 37.1 & $71 \cdot 0^{\$ \$}$ & 96.3 \&\&政 \\
\hline Green yellow Vegetables & 53.0 & $74 \cdot 4^{\$ \$}$ & $117.7 \& \& ¥ ¥$ \\
\hline Vegetables, others & 121.4 & $144.7^{\$ \$}$ & $172.2^{\& \& ¥ ¥}$ \\
\hline Fungi & 4.2 & 5.2 & $6.9^{\&}$ \\
\hline Algae & 4.4 & 6.4 & $8.5^{\& \&}$ \\
\hline Soy-sauce & 14.4 & 16.0 & $21.0 \& ¥$ \\
\hline Worcester-sauces & 2.9 & 2.0 & 2.0 \\
\hline Salts & 1.5 & 1.5 & 1.5 \\
\hline Sake & 121.3 & $80.8^{\$ \$}$ & $48.6^{\& \& ¥}$ \\
\hline Beer & 272.0 & 281.6 & 292.0 \\
\hline Alcoholic beverages & 13.6 & 10.4 & 8.8 \\
\hline Beverages, others & 190.9 & 222.5 & 313.0 \&\&¥¥ \\
\hline Fishes and shellf ishes & 107.5 & 123.3 & $146.8^{8 \& \& ¥}$ \\
\hline Meats & 70.8 & $52.6^{\$ \$}$ & $46.2^{\& \&}$ \\
\hline Eggs & 35.7 & 34.8 & 30.0 \\
\hline Milk products & 82.4 & $134.1^{\$ \$}$ & 170.0 \&\& $¥$ \\
\hline Prepared foods & 1.1 & 1.2 & 1.5 \\
\hline
\end{tabular}

figures are means after adjusting for age according to two-way analysis of variance

$\$: \mathrm{p}<0.05, \$ \$: \mathrm{p}<0.01$, significant difference from Group A

$\&: p<0.05, \& \&: p<0.01$, significant difference from Group A

$¥: \mathrm{p}<0.05,{ }^{¥} \mathrm{p}<0.01$, significant difference from Group B

Table 8 Comparison of intake of foods by food groups according to the $\mathbf{P} /$ Ca ratio (g/day)

\begin{tabular}{|c|c|c|c|}
\hline & Group I & Group II & Group III \\
\hline Cereals & 527.4 & $594.7 \$ \$$ & $605.0^{\& \& \&}$ \\
\hline Nuts and Seeds & 1.3 & 1.4 & 1.0 \\
\hline Potatoes & 39.2 & 38.5 & 33.9 \\
\hline Sugars & 7.1 & 7.0 & 8.8 \\
\hline Confectioneries & 8.6 & 7.1 & 7.1 \\
\hline Fats and Oils & 12.9 & 13.8 & 15.1 \\
\hline Pulses & 122.8 & $94.7 \$ \$$ & $57.5 \& \& ¥ ¥$ \\
\hline Fruits & 81.5 & 63.6 & 66.5 \\
\hline Green yellow Vegetables & 96.8 & 81.3 & $60.0 \& \& \#$ \\
\hline Vegetables, others & 149.5 & 147.3 & 138.8 \\
\hline Fungi & 5.7 & 4.9 & 5.8 \\
\hline Algae & 8.0 & 6.7 & $4.2^{\& \& ¥}$ \\
\hline Soy-sauce & 15.1 & 18.0 & 16.3 \\
\hline Worcester-sauces & 1.7 & 2.2 & 2.8 \\
\hline Salts & 1.2 & $1.6^{\$}$ & $1.6^{\&}$ \\
\hline Sake & 77.9 & 86.0 & 81.6 \\
\hline Beer & 194.3 & 273.5 & 386.4 \&\&¥¥ \\
\hline Alcoholic beverages & 9.8 & 9.0 & 15.5 \\
\hline Beverages, others & 250.6 & 240.8 & 216.5 \\
\hline Fishes and shellf ishes & 112.5 & $128.5^{\$}$ & $131.4^{\&}$ \\
\hline Meats & 40.6 & 51.8 & $78.2^{\& \& ¥ ¥}$ \\
\hline Eggs & 29.5 & 34.8 & $37.3^{\&}$ \\
\hline Milk products & 228.0 & $126.2^{\$ \$}$ & $39.7 \& \& ¥ ¥$ \\
\hline Prepared foods & 1.1 & 1.3 & 1.3 \\
\hline
\end{tabular}

figures are means af ter adjusting for age according to two-way analysis of variance

$\$: p<0.05, \$ \$: p<0.01$, significant difference from Group I

$\&: \mathrm{p}<0.05, \& \&: \mathrm{p}<0.01$, significant difference from Group I

$¥: \mathrm{p}<0.05$, $¥: \mathrm{p}<0.01$, significant difference from Group II 
pared to the other groups, the intake of pulses, green/ yellow vegetables, and milk products was low, while that of beer and meat was high .

In the comparison of the energy intake according to food groups (data not shown in the Table) as well, Group I showed low values for cereals and high values for milk products as compared to the other goups, whereas Group III showed low values for pulses, green/yellow vegetables, and milk products and high values for beer and meat.

4. Comparison of the total energy intake, nutrient intake, RDA nutrient rate and the total score of the dietary habits questionnaire according to the $\mathrm{K} / \mathrm{E}$ ratio and $\mathrm{P} / \mathrm{Ca}$ ratio

As shown in Table 9, in Group $\mathrm{C}$ with a high $\mathrm{K} / \mathrm{E}$ ratio, despite the fact that the total energy intake was low as compared to the other two groups, the intake of nutrients such as $\mathrm{Ca}, \mathrm{P}$, and vitamin A was higher. On the other hand, in Group A with a low $\mathrm{K} / \mathrm{E}$ ratio, the intake of lipids and carbohydrates was high as compared to the other two groups, and so the total energy intake was also higher, although, conversely, the $\mathrm{Ca}$ intake was lower.

In the study on the RDA rate of each nutrient as well, the total energy rate in group $\mathrm{C}$ was low as compared to the other two groups, whereas the rates of other nutrients such as $\mathrm{Ca}, \mathrm{Fe}$ and vitamin A were high, these results being similar to those of the study on nutrient intake.

Furthermore, in the comparison of the total score of the dietary havits questionnaire, Groups $\mathrm{B}$ and $\mathrm{C}$ showed higher scores than Group A.

AS shown in Table 10, in Group I with a low $\mathrm{P} / \mathrm{Ca}$ ratio, total energy intake was low as compared with Group III, whereas the intake of nutrients such as $\mathrm{Fe}, \mathrm{K}$, and vitamin $\mathrm{A}$ was high. In the comparison of Groups I and II as well, although total energy intake was lower in the former, the intake of $\mathrm{Ca}$, vitamin $\mathrm{B} 2$ and vitamin $\mathrm{C}$ was higher. On the other hand, in the compar-

Table 9 Comparison of intake of nutrients, RDA nutrient rate and dietary habits according to the $K / E$ ratio

\begin{tabular}{|c|c|c|c|c|}
\hline & & Group A & Group B & Group C \\
\hline \multicolumn{5}{|l|}{ Intake of nutrients } \\
\hline Total energy & (kcal) & 2177.2 & $2010.1 \$ \$$ & 1877.0 \&\&¥¥ \\
\hline Potassium & (mg) & 1946.6 & $2378.9 \$ \$$ & $2989.2^{\text {\&\&華 }}$ \\
\hline Protein & $(\mathrm{g})$ & 76.4 & 76.8 & $81.8 ¥$ \\
\hline Lipid & $(\mathrm{g})$ & 53.9 & $49.2^{\$}$ & $47.6 \& \&$ \\
\hline Carbohydrates, non-fibrous & $(\mathrm{g})$ & 285.7 & $265.7 \$ \$$ & $242.5 \& \& ¥ ¥$ \\
\hline Calcium & (mg) & 398.5 & $490.3^{\$ \$}$ & $586.9 \& \& ¥ ¥$ \\
\hline Phosphorus & (mg) & 970.7 & $1042.8^{\$}$ & $1127.5 \& \& ¥ ¥$ \\
\hline Iron & (mg) & 8.8 & 8.7 & 10.1 \\
\hline Vitamin A & (IU) & 1535.1 & 1744.1 & $2149.4 \& \& ¥ ¥$ \\
\hline Vitamin B1 & (mg) & 0.9 & 0.8 & 0.9 \\
\hline Vitamin B2 & (mg) & 1.0 & $1.2^{\$}$ & $1.3 \& \& ¥ ¥$ \\
\hline Vitamin $\mathrm{C}$ & $(\mathrm{mg})$ & 47.8 & $69.9 \$ \$$ & 91.6 \&\&¥¥¥ \\
\hline \multicolumn{5}{|l|}{ RDA nutrient rate } \\
\hline Total energy & $(\%)$ & 102.4 & $95.0^{\$ s}$ & $89.0 \& \& ¥ ¥$ \\
\hline Protein & $(\%)$ & 109.3 & 108.4 & $114.9 \quad ¥$ \\
\hline Lipid & $(\%)$ & 103.4 & $93.6^{\$ \$}$ & $91.0 \& \&$ \\
\hline Calcium & $(\%)$ & 67.0 & $79.3 \$ \$$ & $94.2 \& \& ¥ ¥$ \\
\hline Iron & $(\%)$ & 83.2 & $89.8^{\$}$ & $102.8 \& \& ¥ ¥$ \\
\hline Vitamin A & $(\%)$ & 79.8 & 90.4 & $108.2 \& \& ¥$ \\
\hline Vitamin B1 & $(\%)$ & 115.7 & 110.0 & 116.1 \\
\hline Vitamin B2 & $(\%)$ & 97.7 & $107.5^{\$}$ & 120.6 \&\&¥¥ \\
\hline Vitamin $\mathrm{C}$ & $(\%)$ & 100.9 & $139.6 \$ \$$ & 182.9 \&\&¥¥ \\
\hline Total score for dietary habits & & 6.2 & $6.7^{\$}$ & $6.8^{\&}$ \\
\hline
\end{tabular}

figures are means after adjusting for age according to two-way analysis of variance

$\$: p<0.05, \$ \$: p<0.01$, significant difference from Group A

$\&: p<0.05, \& \&: p<0.01$, significant difference from Group $A$

$¥: \mathrm{p}<0.05$, $¥: \mathrm{p}<0.01$, significant difference from Group B

RDA : Recommended Dietary Allowances for Japanese 
Table 10 Comparison of intake of nutrients, RDA nutrient rate and dietary habits according to the $P / C a$ ratio

\begin{tabular}{|c|c|c|c|c|}
\hline & & Group I & Group II & Group III \\
\hline \multicolumn{5}{|l|}{ Intake of nutrients } \\
\hline Phosphorus & $(\mathrm{mg})$ & 1103.2 & $1051.3 \$ \$$ & 987.6 \&\&羊 \\
\hline Calcium & (mg) & 676.1 & $486.8 \$ \$$ & $315.4 \& \& \# ¥$ \\
\hline Total energy & (kcal) & 1939.0 & $2030.7^{\$}$ & $2074.5 \&$ \\
\hline Protein & (g) & 76.2 & 78.7 & 78.3 \\
\hline Lipid & $(\mathrm{g})$ & 50.5 & 49.9 & 49.8 \\
\hline Carbohydrates, non-fibrous & $(\mathrm{g})$ & 254.6 & 268.0 & 269.0 \\
\hline Iron & (mg) & 10.2 & 9.0 & $8.2^{2 \& \&}$ \\
\hline Potassium & (mg) & 2532.6 & 2456.6 & $2246.9 \& \& ¥ ¥$ \\
\hline Vitamin A & (IU) & 1967.5 & 1853.8 & $1496.4^{\& \& \#}$ \\
\hline Vitamin B1 & (mg) & 0.9 & 0.9 & 0.9 \\
\hline Vitamin B2 & (mg) & 1.3 & $1.2^{\$}$ & $1.1 \& \&$ \\
\hline Vitamin C & $(\mathrm{mg})$ & 79.4 & $68.7^{\$}$ & $62.5 \& \&$ \\
\hline \multicolumn{5}{|l|}{ RDA nutrient rate } \\
\hline Total energy & $(\%)$ & 92.3 & 95.9 & $97.3^{\&}$ \\
\hline Protein & $(\%)$ & 107.9 & 111.2 & 110.7 \\
\hline Lipid & $(\%)$ & 96.8 & 94.8 & 95.0 \\
\hline Calcium & $(\%)$ & 107.7 & $79.0^{\$ \$}$ & $54.0 \& \& ¥ ¥$ \\
\hline Iron & $(\%)$ & 96.2 & 92.5 & 84.4 \&\&拜 \\
\hline Vitamin A & $(\%)$ & 101.5 & 95.1 & $76.3^{8 \& \& Y ¥}$ \\
\hline Vitamin B1 & $(\%)$ & 113.6 & 110.8 & 116.7 \\
\hline Vitamin B2 & $(\%)$ & 117.0 & 107.9 & $100.5 \& \&$ \\
\hline Vitamin C & $(\%)$ & 160.9 & $137.8^{\$ \$}$ & $126.3^{2} \& \&$ \\
\hline Total score for dietary habits & & 6.7 & 6.7 & 6.3 \\
\hline
\end{tabular}

figures are means after adjusting for age according to two-way analysis of variance

$\$: p<0.05, \$ \$: p<0.01$, signif icant difference from Group I

$\&: p<0.05, \& \&: p<0.01$, significant difference from Group I

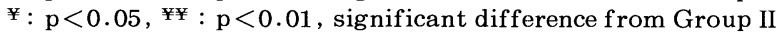

RDA : Recommended Dietary Allowances for Japanese

ison of Groups II and III, no differences were found in the intake of energy while the intake of $\mathrm{K}$ and vitamin $\mathrm{A}$ was higher in the former.

Looking at these RDA nutrient rates, the total energy rate of Group I was lower than that of Group III. Conversely, those of nutrients such as iron and vitamin A were higher, showing a tendency similar to the results of the comparison of intake of nutrients.

However, no significant differences were found among the three groups in the total score of the dietary habits questionnaire.

\section{Discussion}

Reflecting the recent economic development of Japan the dietary circumstances of the people have undergone rapid change. On the one hand, a wide variety of foods has become readily available, while on the other the number of consumed foods has decreased because the taking of meals has become irregular, the consumption of animal and processed foods has increased, and mealtimes have become shorter, with these factors giving rise to an imbalance in the intake of nutrients ${ }^{1 \sim 3}$ ).

The authors previously investigated the influence exerted by poor dietary havits such as skipping meals and late-night eating on obesity and the intake of each kind of nutrient in the same population studied here ${ }^{16,17)}$. Our results revealed that in the group with poor dietary habits, the proportion of overweight persons was greater than that in the group with good dietary habits ${ }^{16)}$. However, even when many poor dietary habits were present but the total energy intake was within or below the suitable range, obesity did not develop, although an influence on the intake of other nutrients was observed ${ }^{17)}$. Shiraki et al. ${ }^{18)}$ similarly reported that in groups with the same total energy intake, such poor dietary habits had a major influence on the unbalanced intake of minerals. That is, over consumption 
of animal and processed foods leads to excessive consumption of $\mathrm{P}$. Insufficient consumption of vegetables and fruits associated with a decrease in the number of foods selected results in a decrease in the amount of $\mathrm{K}$ consumed, and moreover, insufficient consumption of milk products and small fish leads to inadequate Ca consumption. In this way, it was thought that the balance of intake of minerals suggests the quality of nutrition. In a recent National Nutrition Survey ${ }^{19)}$ as well, the intake of nutrients such as $\mathrm{Ca}$ and Fe was noted to be insufficient and to require particular attention in the diet.

At first, based on the conventionally used RDA nutrient rates ${ }^{20,21)}$, we performed comparisons of the intake and nutrients rates according to $\mathrm{RDA}$ rates of total energy or $\mathrm{Ca}$. Comparisons according to the RDA energy rate were indeed effective for investigating the relation between RDA total energy rate and BMI and between RDA total energy rate and the total score on the dietary habits questionnaire. However, although none of the water-soluble RDA vitamins rates in the group showed an appropriate RDA total energy rate of $\geqq 90$, the $\leqq 110 \%$ group showed less than $100 \%$, the RDA protein rate was $113.6 \%$ and that of $\mathrm{Ca} 81 \%$, both of which were clearly less than desirable (Table 5). On the other hand, comparing the RDA Ca rate as well, the RDA protein rate was $114.9 \%$ even in the groups with RDA Ca rates $\geqq 90$ and $\leqq 110 \%$. The influence of low $\mathrm{Ca}$ intake has already been demonstrated ${ }^{8)}$, and it is also known that a high protein intake enhances the urinary excretion of $\mathrm{Ca}$, leading to a negative $\mathrm{Ca}$ balance ${ }^{22)}$. These results suggest that studies focusing on the intake of total energy alone or individual nutrients may be inadequate.

Based on above results, we performed a study of groups divided according to $\mathrm{K} / \mathrm{E}$ ratio and $\mathrm{P} / \mathrm{Ca}$ ratio. Group $\mathrm{C}$ with a high $\mathrm{K} / \mathrm{E}$ ratio showed less consumption of cereals, fats/oils, and Japanese rice wine and more consumption of pulses and vegetables as compated to Group
A with a low $\mathrm{K} / \mathrm{E}$ ratio. As a result, although the RDA protein rate of Group $\mathrm{C}$ was high, this group showed an appropriate intake of vitamins and minerals and a dietary content markedly more favorable than that of Group A with a low $\mathrm{K} / \mathrm{E}$ ratio. The total score on the dietary habits questionnaire also showed higher values in this group (Tables 7, 9). Group I with a low P/Ca ratio, as compared to Group III with a high $\mathrm{P} / \mathrm{Ca}$ ratio, showed higher consumption of pulses, vegetables, and milk products and lower consumption of cereals, meat, and beer. As a result, the total score on the dietary habits questionnaire did not differ among the three groups because the questions on it were mostly related to overeating. However, a favorable balance of food groups and nutrients was confirmed in Group I, which showed values for all items within $10 \%$ of desirable values. Also, as compared to the differences of the RDA rates of total energy, protein and lipid in the three groups divided according to the $\mathrm{P} / \mathrm{Ca}$, those in minerals and vitamins were considerable more striking (Table 8,10 ).

From the above results it was surmised that the $\mathrm{K} / \mathrm{E}$ ratio reflects the balance of nutrient intakes, taking into account total energy intake, while the $\mathrm{P} / \mathrm{Ca}$ ratio reflects the balance of mineral intake without being unduly influenced by the total energy intake.

It has been recognized that the unbalanced intake of nutrients over protracted periods is a risk factor for various adult diseases ${ }^{23)}$. It is necessary to again recognize that, for a nutrient to be properly taken up and used by the body, numerous other nutrients play a role, with the health of the body maintained by the interactions among these nutrients. For this reason, it is important that excessive reliance not be placed on fast and processed foods, and that as many different kinds of foods as possible be consumed at the appropriate times and in appropriate amounts.

\section{Acknowledgments}

The authors express their deep gratitude to 
Prof . S. Goto of the Department of Nutrition, Tokyo University of Agreculture for his valuable advice. We are also grateful to dietitians Ritsuko Kimura, Hitomi Sako, Kazuko Toda, and Rumi Takeda of the Division of Nutrition, Kanazawa Medical University Hospital for their help in conducting the nutrition surveys.

\section{References}

1) Uehara, M., Suzuki, K. and Goto, S.: The effects of dietary phosphorus and magnesium levels on iron, copper and zinc utilization in rats, J. Jpn. Soc. Mg Res. , 11, 145-153 (1992).

2 ) Nakamura, T., Kawashima, Y., Saishoji, S., Nakayama, K. and Hosoya, K.: Studies on physical status and eating behavior in overweight subjects, Jpn. J. Nutr., 44, 4551 (1986) . (in Japanese)

3 ) Yoshita, K., Nakagawa, H., Tabata, M., Morikawa, Y., Senma, M., Nishijo, M., Takase, E., Ishizaki, M., Yamada, Y., Kido, T. and Kawano, S.: The influence of job-related separation from their home on dietary habit, intake of nutrients and health examination results, Jpn. Assoc. Cerebrocardiovasc. Dis. Cont., 28, 37-41 (1993). (in Japanese with English abstract)

4 ) Hirota, T. and Hirota, K.: Shokuji, daietto to biryogenso [Meal, dietetics and trace elements], J. Ther., 75, 989-998 (1993). (in Japanese)

5 ) Iwao, H.: Rinsan no shoyoryo [The phosphorus rate of Recommended Dietary Allowance for Japanese], In "Rin no hataraki [The function of phosphate]" (Editors: Ohara, T. , Iwao, H. and Fukuba, H.), p.135-144, Daiichi Shuppan, Tokyo (1983). (in Japanese)

6 ) Hosoya, K. : Kakoshokuhin to eiyo no mondai [Problems of processed foods and nutrition], In "Kakoshokuhin to eiyo [Processed foods and nutrition]" (Editor: Hosoya , K.), p.1-12, Daiichi Shuppan, Tokyo (1985). (in Japanese)
7 ) Ishida, H.: Marginal zinc deficiency and gustatory function for salt in a group of healthy young adult women, J. Jpn. Soc. Nutr. Food Sci. , 46, 299-307 (1993). (in Japanese with English abstract)

8 ) Goto, S.: Minerals and diseases, Biol. Nutr. , 10, 47-52 (1986). (in Japanese with English abstract)

9 ) Iguchi, M., Kataoka, K., Kohri, K., Yachiku, S. , Kurita, T. , Nakano, K., Kimura, A. and Sasaki, I. : Nutritional studies on the patients with renal stone disease, $\mathrm{J}$. Jpn. Soc. Nutr. Food Sci., 37, 1-7 (1984). (in Japanese with English abstract)

10) Karpannen, H. , Pennanen, R. and Passinen, L. : Minerals and coronary heart disease and coronary sudden death, Adv. Cardiol. , 25, 9-18 (1978) .

11) Resources Council, Science and Technology Agency, Japan: Yonteiban nippon shokuhin hyojun seibunhyo [Standard tables of food composition in Japan, Fourth revised edition-1982-], Statistics Bureau, Ministry of Finance of Japan, Tokyo (1982). (in Japanese)

12) Health Promotion and Nutrition Division, Health Service Bureau, Ministry of Health and Welfare of Japan: Heisei 2 nen ban kokumin eiyo no genjo [The present condition of national nutrition in 1988], p.10-13, Daiichi Shuppan, Tokyo (1990). (in Japanese)

13) Health Promotion and Nutrition Division, Health Service Bureau, Ministry of Health and Welfare of Japan: Recommended dietary allowances of the Japaneses, - Fourth Revision-, Daiichi Shuppan, Tokyo (1991).

14) Tanaka, T. : 2 inshi yoin jikken [Two-way analysis of variance], In "Pasokon tokei handobukku III Jikken keikaku ho [Handbook of statistical methods for personal computers III, Design and analysis of experiments" (Editors: Tanaka, T. and Tarumi, T.), p.42-59, Kyoritsu Shuppan, Tokyo (1986). (in Japanese) 
15) Tanaka, T. : 1 inshi jikken [One-way analysis of variance], In "Pasokon tokei handobukku III Jikken keikaku ho [Handbook of statistical methods for personal computers III, Design and analysis of experiments" (Editors: Tanaka, T. and Tarumi, T.), p.1-15, Kyoritsu Shuppan, Tokyo (1986). (in Japanese)

16) Yoshita, K., Tabata, M., Morikawa, Y., Kitagawa, Y., Senma, M., Kawano, S. , Takase, E., Nishijo, M., Nakagawa, H., Ishizaki, M., Yamada, Y. and Kido, T. : The relationship between eating behavior and clinical features in overweight men, Hokuriku J. Public Health, 18, 38-44 (1991). (in Japanese with English abstract)

17) Yoshita, K., Tabata, M., Morikawa, Y., Senma, M., Kawano, S., Ishizaki, M., Yamada, Y., Takase, E. , Nishijo, M. and Nakagawa, H. : A study of influences of eating behavior and body mass index on the intake of nutrients, Hokuriku J. Public Health, 19, 36-43 (1992) . (in Japanese with English abstract)

18) Shiraki, M. and Fukaya, N.: Food intake patterns investigated through high/low intake ratios of calcium and iron to RDA, Jpn. J. Nutr. , 46, 85-94 (1988). (in Japanese with English abstract)

19) Health Promotion and Nutrition Division,
Health Service Bureau, Ministry of Health and Welfare of Japan: Heisei 4 nen ban kokumin eiyo no genjo [The present condition of national nutrition in 1990], p.35-36, Daiichi Shuppan, Tokyo (1992). (in Japanese)

20) Health Promotion and Nutrition Division, Health Service Bureau, Ministry of Health and Welfare of Japan: Heisei 3 nen ban kokumin eiyo no genjo [The present condition of national nutrition in 1989], p.90-91, Daiichi Shuppan, Tokyo (1991). (in Japanese)

21) Health Promotion and Nutrition Division, Health Service Bureau, Ministry of Health and Welfare of Japan: Heisei 4 nen ban kokumin eiyo no genjo [The present condition of national nutrition in 1990], p.88-89, Daiichi, Shuppan, Tokyo (1992). (in Japanese)

22) Goto, S. : Karushumu riyo ni eikyo wo oyobosu kanrenbusshitsu [Related-substances effects on utilization of calcium], Jpn. J. Clin. Nutr . , 74, 589-596 (1989). (in Japanese)

23) Health Promotion and Nutrition Division, Health Service Bureau, Ministry of Health and Welfare of Japan: Kenko zukuri no tameno shokuseikatsu shishin [A guide to dietary intakes for better health], Daiichi Shuppan, Tokyo (1991). (in Japanese)

(Received May 17, 1993/Accepted Oct. 27, 1993) 